\title{
Faktor Lingkungan Sosial, Lingkungan Fisik, dan Pengendalian Program DBD terhadap Kejadian Demam Berdarah Dengue (DBD)
}

\author{
Bambang Murwanto $^{1}$, Sri Indra Trigunarso ${ }^{2}$, Purwono ${ }^{3}$ \\ Jurusan Kesehatan Lingkungan, Politeknik Kesehatan Tanjungkarang, Indonesia \\ Email: bambang_murwanto@poltekkes-tjk.ac.id
}

\begin{abstract}
Factors of Social Environment, Physical Environment, and Control of Dengue Fever Program Dengue Hemorrhagic Fever (DHF). Dengue Bedarah Fever (DHF) one of the problem of the disease in Indonesia and including 30 countries in the world endemic for dengue disease, even though be second place disease in 2015 with a Case Fatality Rate (CFR) of $0.95 \%$. Besides in Lampung in the last three years (2014-2016) tendency for Incidence Rate (IR) is increasing. In South Lampung Regency as the gateway to Sumatra Island in 2017 the Incidence Rate (IR) averaged $20.78 \%$ and one of the highest Incidence Rate (IR) reached $70.59 \%$ in the Hajimena Health Center Working Area, Natar District. The purpose of this study was to find out the relationship between the factors of the Social Environment, Physical Environment, and the Factors of Controlling the DHF Control Program, and factors were the most dominant relationships. The research method is quantitative with the Cross-Sectional approach, with the study population in the Hajimena Community Health Center Working Area, Natar District, which includes three villages namely Hajimena village, Sidosari village, and the Pemanggilan village. Primary data is taken using questionnaires and checklists, and secondary data is sourced from Puskesmas and Kecamatan. Processing data using data processing software by analyzing using univariate, and bivariate methods. The results of this study show that there is a meaningful relationship are the mobility of the population with the incidence of disease. To eradicate dengue in the Natar sub-district, especially the Hajimena Public Health Center area which is an endemic area, it also requires comprehensive and integrated activities, namely PSN-DBD with periodic larvae checks by cadres of the Larvas Monitoring.
\end{abstract}

Keywords: Aedes aegypti, DHF (Dengue Hemorrhagic Fever), Environment

\begin{abstract}
Abstrak: Faktor Lingkungan Sosial, Lingkungan Fisik, dan Pengendalian Program DBD terhadap Kejadian Demam Berdarah Dengue (DBD). Penyakit Demam Bedarah Dengue (DBD) masih menjadi masalah penyakit di Indonesia dan Indonesia termasuk 30 negara di dunia endemis penyakit DBD, bahkan menjadi menyakit urutan kedua pada tahun 2015 dengan tingkat Case Fatality Rate (CFR) 0,95\%. Demikian pula di provisi Lampung dalam tiga tahun terakhir (2014-2016) kecenderungan Incidence Rate (IR) makin meningkat. Di Kabupaten Lampung Selatan sebagai pintu gerbang pulau Sumatra pada tahun 2017 Incidence Rate (IR)nya rerata mencapai 20,78\% dan salah satu Incidence Rate (IR) tertinggi yaitu mencapai 70,59\% di Wilayah Kerja Puskesmas Hajimena, Kecamatan Natar. Tujuan penelitian ini untuk mencari hubungan faktor-faktor Lingkungan Sosial, Lingkungan Fisik, dan Faktor-faktor Pengendalian Program Penanggulangan DBD, dan factor apa saja yang hubungannya paling dominan. Metode penelitian bersifat kuantitatif dengan pendekatan Cross Sectional, dengan populasi penelitian di Wilayah Kerja Puskesmas Hajimena, Kecamatan Natar, yang meliputi tiga desa yaitu Desa Hajimena, Desa Sidosari dan desa Pemanggilan. Data primer diambil dengan menggunakan kuesioner dan ceklis, dan data sekunder bersumber dari Puskesmas dan Kecamatan. Pengolahan data menggunakan soft ware olah data dengan dianalisis menggunakan metode univariat, dan bivariat. Hasil penelitian ini menunjukankan adanya hubungan bermakna mobilitas penduduk dengan kejadian penyakit. Agar memberantas penyakit DBD di wilayah kecamatan Natar, khususnya wilayah UPT Puskesmas Hajimena yang merupakan daerah endemis, naka diperlaukan kegiatan yang bersifat menyuluruh dan terintegrasi yaitu PSN-DBD dengan pemeriksaan jentik berkala oleh kader Juru Pemantau Jentik (Jumantik).
\end{abstract}

Kata kunci: Aedes aegypti, DBD (Demam Berdarah Dengue), Lingkungan 


\section{PENDAHULUAN}

Penyakit DBD termasuk salah satu masalah kesehatan masyarakat yang utama di Indonesia. Penyakit ini pertama kali dilaporkan setelah adanya kejadian luar biasa (KLB) di Jakarta dan Surabaya pada tahun 1968. Demam Berdarah Dengue (DBD) merupakan salah satu penyakit infeksi virus yang penyebarannya dilakukan oleh nyamuk Aedes aegypti (Rulen, dkk., 2017).

Tujuan pembangunan kesehatan nasional adalah meningkatkan derajat kesehatan, dengan menurunkan angka kematian (mortalitas) dan kesakitan (morbiditas). Salah satu angka kematian (mortalitas) dan kesakitan (morbiditas) yang masih menjadi masalah utama adalah penyakit Demam Berdarah Dengue (DBD), karena penyakit yang bersifat akut ini selain dapat menyebabkan kesakitan (Incidence Rate atau $I R$ ) sering dapat menyebabkan kematian yang dapat dilihat dari angka Case Fatality Rate $(C F R)$ terutama pada bayi dan anak. Secara global Indonesia termasuk dalam 30 negara endemis DBD (CNN Indonesia, 2018), bahkan sempat menjadi urutan kedua pada tahun 2015 dengan Case Fataloity Rate (CFR) pada waktu itu mencapai 0,95\%.

Penyebaran dan tinggi rendahnya angka kesakitan demam berdarah dipengaruhi oleh beberapa faktor diantaranya tinggi rendahnya populasi vektor, virulensi virus, imunitas penduduk, kepadatan penduduk, mobilitas penderita dan kemampuan virus memperbanyak diri dalam tubuh nyamuk serta perilaku manusia yang dapat memberi peluang tempat perkembangbiakan nyamuk (Yunita, dkk., 2012).

Dari hasil wawancara dengan pihak Dinas Kesehatan Kabupaten Lampung Selatan, Tahun 2017 rerata angka Incidence Rate (IR) 20,78, dimana kecamatan tertinggi ada di wilayah Kecamatan Natar. Hal ini dikarenakan Kecamatan Natar merupakan kecamatan penyangga daerah perkotaan yaitu kota Bandar Lampung, sehingga penduduknya relatif padat. Sebagai daerah yang cenderung urban tersebut member peluang untuk terjadinya endemisitas penyakit DBD. Salah satu wilayah Kecamatan Natar, yaitu wilayah Puskesmas Hajimena pada Tahun 2019 lalumencapai 16 kejadian DBD dengan Incidence Rate (IR) mencapai 70,59\%.

Pola kejadian penyakit DBD di Kabupaten Lampung Selatan, yaitu pada musim penghujan (awal dan akhir tahun) adanya peluang terdapat air hjan yang tergenang yaitu merupakan breeding place atau tempat perindukan nyamuk Adedes aegypty sebagai vektor penyakit DBD seperti pada gambaran yang terjadi pada penderita penyakit DBD yang dirawat di RSUD dr. Hb. Bob Bazar, SKM pada tahun 2012 (Murwanto, 2013). Seperti terjadi juga di Kota Bogor ada hubungan bermakna antara kejadian DBD dengan iklim (suhu, curah hujan, kelembamam, lama penyinaran mata hari dan kecepatan angin (Silaban dalam Murwanto, 2013).

Keadaan kesehatan seperti di Kabupaten Lampung yang telah disebutkan di atas selain dipengaruhi oleh berbagai faktor lingkungan sebagi yang terbesar, dan faktor perilaku masyarakat sebagai terbesar kedua (Green and Kreuter, 2005). Pengaruh perilaku tersebut secara umum tergambar oleh Angka Proporsi Rumah Tangga yang memenuhi kriteria Perilaku Hidup Bersih dan Sehat (PHBS) provinsi Lampung tahun 2013 sekitar 20\% atau masih dibawah ratarata nasional yang mencapai $32,3 \%$ dan gambaran Angka Bebas Jentik (ABJ) seperti tersebut di atas.

Tujuan penelitian mengetahui faktor lingkungan sosial, lingkungan fisik, dan faktor pengendalian program DBD terhadap kejadian Demam Berdarah Dengue (DBD) di Wilayah Kerja Puskesmas Hajimena, Kabupaten Lampung Selatan, pada tahun 2018.

\section{METODE}

Metode penelitian ini bersifat observasional dan jenis penelitian bersifat kuantitatif, dengan pendekatan potong lintang (Cross Sectional). Subyek penelitian adalah Kepala Keluarga (KK) masyarakat di Wilayah Puskesmas Hajimena, Kecamatan Natar, untuk mengetahui hubungan faktor-faktor Lingkungan Sosail, Lingkungan Fisik dan Pengendalian Program dengan Kejadian DBD. Pada saat penelitian tim enumerator dilengkapi lembar Inform Concern sebagai bagian dari Keterangan Kelaikan Etik yang dikeluarkan oleh Komisi Etik Penelitian Kesehatan Politeknik Kesehatan Tanjung Karang No. 158/EC/KEP-TJK/VI/2018.

Waktu penelitian ini adalah bulan Juni sampai dengan November Tahun 2018 dengan lokasi penelitian ini dilaksanakan di Wilayah Puskesmas Hajimena, Kec. Natar Kabupaten Lampung Selatan.

Populasi penelitian ini berjumlah 7.147 $\mathrm{KK}$, dengan nilai $\mathrm{Z}_{1-\dot{\alpha} / 2}=1,86$ dan tingkat kepercayaan 95\%, Maka di dapat jumlah (besar) sampel sebanyak 84,7 KK dan dibulatkan menjadi $90 \mathrm{KK}$. Metode pengambilan sampel 
dengan teknik Propotional Random Sampling (Notoadmodjo, 2010).

Analisis data menggunakan aplikasi pengolah data komputer (soft ware) dengan menggunakan analisis Univariat dan Bivariat. Analisis Univariat digunakan untuk analisis distribusi frekuensi yaitu penyebaran kreteria hasil masing-masing variabel. Analisis Bivariat digunakan untuk mengetahui hubungan antara variabel bebas dengan variabel terikat.

\section{HASIL}

Tabel 1. Gambaran Distribusi Variabel Dependen dan Variabel Independen

\begin{tabular}{|c|c|c|}
\hline Variabel & Kriteria Hasil & Hasil \\
\hline Kejadian & Menderita & $19 \%$ \\
\hline Penyakit & Tidak menderita & $81 \%$ \\
\hline Kepadatan & Padat & $54 \%$ \\
\hline Hunian & Tidak Padat & $46 \%$ \\
\hline Mobilitas & Ada Mobilitas & $78,9 \%$ \\
\hline Penduduk & Tidak ada mobilitas & $21,1 \%$ \\
\hline Kondisi SPAL & Baik & $48 \%$ \\
\hline & Buruk & $52 \%$ \\
\hline Keberadaan Ban & Ada ban bekas & $1,1 \%$ \\
\hline Bekas & $\begin{array}{l}\text { Tidak ada Ban } \\
\text { Bekas }\end{array}$ & $98,9 \%$ \\
\hline Keberadaan & Baik & $91,1 \%$ \\
\hline Sumur Gali & Buruk & $8,9 \%$ \\
\hline
\end{tabular}

Tabel 2. Hubungan Bivariat antara Variabel Penyakit dan Determinan pada Variabel Bebas

\begin{tabular}{lrcc}
\hline $\begin{array}{c}\text { Variabel } \\
\text { Bebas }\end{array}$ & $\begin{array}{c}\text { OR } \\
\mathbf{9 5 \% )}\end{array}$ & $\begin{array}{c}\boldsymbol{p} \text { - } \\
\text { value }\end{array}$ & Signifikasi \\
\hline Faktor Lingkungan Sosial & & \\
\hline Kepadatan & 1,245 & 0,895 & Tidak \\
Hunian & $(0,427-3,630)$ & & Signifikan \\
Mobilitas & 1,315 & 0,042 & Signifikan \\
Penduduk & $(1,154-1,498$ & & \\
\hline Faktor Lingkungan Fisik & & \\
\hline Kondisi & 2,60 & \multirow{2}{*}{0,157} & Tidak \\
SPAL & $(0,833-8,146)$ & & Signifikan \\
Keberadaan & 0,775 & 0,839 & Tidak \\
Ban Bekas & $(0,269-2,231)$ & Signifikan \\
Keberadaan & 0,672 & 0,001 & Tidak \\
Sumur Gali & $(0,123-3,66)$ & & Signifikan \\
\hline Faktor Pengendalian Program DBD & \\
\hline Kegiatan & 2,22 & & Tidak \\
Penyuluhan & $(0,742-6,651)$ & 0,238 & Signifikan \\
DBD & 4,44 & & Tidak \\
Kader & 0,105 & Signifikan \\
Jumantik & $(0,911-13,03)$ & & Tidak \\
Gerakan & 0,699 & 0,712 & Signifikan \\
PSN DBD & $(0,233-2,093)$ & & Tidak \\
Kegiatan & 1,095 & 1,000 & Signifikan \\
Fogging & $(0,380-3,150$ & & \\
\hline
\end{tabular}

Dari hasil analisis univariat yang tergambar pada tabel 1 bahwa yang nampak cukup besar hasilnya adalah determinan mobilitas penduduk, memang $78,9 \%$ ini berarti sebagian besar penduduk setiap harinya mencari mata pencaharian di luar wilayah kerja UPT Puskesmas Hajimena. Determinan lain adalah ketiadaan ban bekas $(98,1 \%)$, kondisi sumur gali yang baik $(91,1 \%)$.

Sedangkan dari 9 variabel bebas pada tabel 2 hanya 1 variabel yang mempunyai hubungan yang bermakna (signifikan) yaitu mobilitas penduduk p-value 0,042 dan OR mencapai 1,315 (1,154-1,498).

\section{PEMBAHASAN}

Pada saat penelitian ini dilaksanakan di lapangan pada sekitar bulan September 2018 adalah saat-saat musim panca roba dari musim hujan ke musim kemarau. Jadi sudah terasa musim panas dengan meningkatnya suhu udara, namun cuaca terkadang masih diselingi oleh curah hujan yang cukup besar. Pada saat penelitian tersebut dari laporan Puskesmas sudah ditemukan kasus baru sekitar 14 orang. Kondisi cuaca dan suhu tertentu yang menjadi cirri khas terjadinya penyakit DBD teutama pada daerahdaerah endemis, yang terjadi di daerah lain seperti di DKI Jakarta Tahun 2017 (Lutfi, dkk., 2017), di Sukabumi tahun 2016 (Hidayati, dkk., 2017), pengaruh iklim juga terjadi di kota Bogor dimana peningkatan curah hujan akan meningkatan insiden DBD (Silaban dalam Murwanto, 2013).

\section{Hubungan Kepadatan Hunian Penduduk dengan Kejadian Penyakit DBD}

Variabel kepadatan hunian rumah tidak berhubungan dengan kejadian penyakit $\mathrm{DBD}$, ini berarti semakin padat atau banyak penghuni rumah tidak beresiko terjadinya penularan. Hal ini konsisten dengan variabel mobilitas yang telah dijelaskan di atas. Walaupun tingginya kepadatan hunian, namun karena mobilitas penduduk yang tinggi yaitu 78,9\%, maka kemungkinan tertular lebih kecil di tempat tinggalnya, mungkin sebagian besar mereka tertular di tempat lain, di tempat mobiltasnya biasa berada. Sehingga ada kemungkinan tingginya angka endemis DBD di wilayah UPT Puskesmas Hajimena adalah kumpulan penderita 
yang tertular di wilayah tersebut dan di wilayah lain.

\section{Hubungan Mobilitas Penduduk dengan Kejadian Penyakit DBD}

Sesuai dengan penelitian ini selain kondisi cuaca dan iklim (yang tidak diteliti dalam penelitian ini), kondisi kepadatan rumah dan penghuni yang menjadi karakter lingkungan yang sama seperti di daerah penelitian ini, dan di DKI Jakarta dan Sukabumi seperti disebutkan di atas. Pada penelitian ini hanya satu variabel yang mempunyai hubungan yang bermakna yaitu mobilitas penduduk dengan kejadian DBD. Daerah penelitian yang merupakan daerah penyangga (buffer zone) kota Bandar Lampung sehingga penduduknya banyak bekerja di kota tersebut sehingga status mobilitasnya adalah "Nglaju" (Mantra. 2008), dan penduduk yang Nglaju tersebut cukup tinggi yaitu mencapai $78,9 \%$, sehingga memberi peluang untuk terjadinya penularan penyakit DBD kemungkinan justru dari daerah lain. Demikian pula peranan mobilitas penduduk terhadap penularan penyakit DBD juga terjadi di Denpasar Bali (Subagia, K., dkk., 2012). Bahkan di desa Mojosongo, Kabupaten Boyolali, peranan mobilitas penduduk pada penularan DBD memiliki resiko 9,29 kali (Gama dan Betty, 2010). Di wilayah UPT Puskesmas Natar yang bersebelahan dan satu kecamatan dengan wilayah UPT Puskesmas Hajimena, jenis pekerjaan yang memerlukan mobilitas $(69,6 \%)$ seperti pedagang, petani, wiraswasta, TNI/Polri, dsb, adalah penderita DBD tahun 2015 (Murwanto, 2015).

\section{Hubungan Saluran Pembuangan Air Limbah (SPAL) dengan Kejadian Penyakit DBD}

Saluran Pembuangan Air Limbah (SPAL) tidak ada hubungan yang bermakna dengan kejadian penyakit DBD, karena dua alasan pertama adalah air yang keluar dari SPAL langsung berhubungan dengan tanah, kedua sebelum keluar airnyapun sudah kotor (maksudnya tidak jernih seperti air hujan) sehingga tidak member peluang untuk terjadinya tempat perindukan nyamuk Aedes aegypti sebagai vektor penyakit DBD (Silaban dalam Murwanto, 2013).

\section{Hubungan Keberadaan Ban Bekas dengan Kejadian Penyakit DBD}

Demikian pula mayoritas penduduk tidak memiliki ban bekas di sekitar pemukiman yang artinya tidak memberi peluang bagi air hujan untuk terjadinya genangan, dimana ban bekas menjadi peluang bagi terjadinya tempat perindukan nyamuk Aedes aegypti sebagai vektor penyakit DBD. Hal serupa juga terjadi di wilayah Puskesmas Gantung Payung, Kalimantan Selatan yang sebagian besar masyarakatnya tidak buang barang-barang bekas disekitar rumah (Irianty, dkk., 2017).

Ban bekas merupakan salah satu tempat penampungan air yang keberadaannya sering terabaikan padahal merupakan tempat keberadaan jentik nyamuk. Keberadaan jentik berhubungan dengan lingkungan fisik tempat penampungan air dan keberadaan kontainer di luar rumah. Sistem penyimpanan air merupakan metoda dasar dalam mengendalikan nyamuk Aedes terutama Aedes aegypti (Rulen, 2017).

Seperti dikemukakan Pham HV., et al, (2011) yang menyatakan bahwa keberadaan tempat penampungan air yang berjentik berhubungan dengan kejadian DBD.

\section{Hubungan Sumur Gali dengan Kejadian Penyakit DBD}

Keadaan variabel sumur gali dengan kondisi yang sangat baik yaitu mencapai $91,1 \%$, sehingga tidak tidak hubungan yang berakna terhadap kejadian penyakit DBD. Kondisi tersebut dimaksud adalah kondisi sumur gali yang mempunyai dinding atau cincin pagar dari adukan batu semen termasuk batu bata setinggi minimal 1,5 meter dari lantai. Adanya dinding atau cincin dari adukan batu semen termasuk batu bata 2 meter kebawah dari lantai yang mengelilingi dinding sumur bagian atas. Kemudian adanya lantai dari adukan batu semen termasuk batu bata yang mengelilingi sumur berjarak 2 meter dari dinding sumur. Kondisi senada adalah kondisi lingkungan yang baik juga terjadi di Kabupaten Jember yang tidak berhungan dengan kejadian penyakit DBD (Sholehhudin, dkk., 2014). Sumur Gali juga dapat menjadi tempat perindukan jentik nyamuk Aedes spp. termasuk Aedes albopictus juga terjadi kelurahan Bulusan Kota Semarang (Said, dan Palupi, 2012).

\section{Hubungan Penyuluhan DBD dengan Kejadian Penyakit DBD}

Kegiatan penyuluhan DBD dengan kriteria baik mencapai $51 \%$, tapi tidak ada hubungan yang bermakna dengan kejadian peyakit DBD. Artinya kegiatan penyuluhan memberi dampak yang baik bagi penurunan kejadian DBD. 
Namun, kegiatan penyuluhan seharusnya didukung oleh hasil kegiatan surveilans oleh petugas Puskesmas, hal serupa yang tidak mempunyai hubungan yang bermakna juga terjadi di kelurahan Kramas Kota Semarang (Istiqomah, dkk., 2017).

\section{Hubungan Keberadaan Kader Jumantik dengan Kejadian Penyakit DBD}

Adanya variabel kader jumantik yang hanya $38 \%$ atau sedikit tersebut tidak ada hubungan yang bermakna dengan kejadian penyakit DBD. Hal ini berarti meskipun jumlah kader jumantik relatif sedikit tersebut tidak menimbulkan kejadian penyakit DBD. Namun agar dapat memberi akses atau dorongan menurunkan kejadian penyakit DBD maka kegiatan kader jumantik harus diperluas dan dintegrasikan dengan kegiatan PSN-DBD. Seperti di Kelurahan Jomlah, Kecamatan Candisari, Kota Semarang, kegiatan kader Jumantik terintegrasi dengan PSN-DBD dan $3 \mathrm{M}$ Plus (Tanjung, 2012), dan untuk meningkatakan kinerja kader melalui peningkatan faktor predisposing, enabling dan reinforcing. Kegiatan lain adalah melakukan kegiatan $3 \mathrm{M}$ di rumah masing-masing dan penyuluhan langsung, seperti di kota Denpasar (Hadi, dkk., 2015).

\section{Hubungan Gerakan PSN-DBD dengan Kejadian Penyakit DBD}

Gerakan PSN-DBD yang hanya 57,8\% juga tidak ada hubungan yang bermakna dengan kejadian penyakit DBD. Dalam hal ini berarti kegiatan PSN-DBD tidak membantu penurunan kejadian penyakit DBD secara bermakna. Gerakan PSN-DBD agar ditingkatkan lagi untuk dapat "mendongkrak" upaya penurunan kejadian penyakit DBD misalnya dengan menambahkan gerakan 3 M Plus (Menutup, Menguras dan Mengubur tempat-tempat bersarang nyamuk Aedes aegypti) plus pemberian obat penurun panas seperti yang dilakukan di wilayah Puskesmas Guntung Payung, Kalimantan Selatan (Irianty, dkk., 2017), dan pemberian bubuk abate. Melalui Gerakan PSN-DBD yang intinya juga mengenai kebijakan pemerintah berkaitan dengan pemberantasan penyakit DBD maka kegiatannya juga diperluas yaitu memberikan deteksi dini atau membuat early warning system bagi pemerintah untuk memberikan "alarm" atau perhatian pada waktu-waktu tertentu yang biasa terjadinya penyakit DBD, dengan bekerja sama dengan BMKG setempat (Lutfi, dkk., 2017).

\section{Hubungan Kegiatan Fogging dengan Kejadian Penyakit DBD}

Kegiatan fogging yang sesuai dengan prosedur mencapai $87,8 \%$ tidak berhubungan dengan kejadian penyakit DBD. Berarti dengan kegiatan fogging yang selama ini dilakukan tidak memberi dampak pada penurunan kejadian penyakit DBD. Hal tersebut terjadi karena memang upaya fogging tidak langsung memutus mata rantai penularan karena yang diberantas hanya nyamuk dewasa saja, sedangkan jentikjentik nyamuk Aedes aegypti masih tetap hidup dan berkembang (Nugrahaningsih, dkk., 2010). Oleh sebab itu kebijakan yang paling tepat adalah dengan memberantas jentik-jentik nyamuk melalui program PSN-DBD dengan $3 \mathrm{M}$ Plus seperti yang disarankan di wilayah Puskesmas Guntung Payung, Kalimantan Selatan (Irianty, dkk., 2017).

\section{SIMPULAN}

Berdasarkan hubungan faktor-faktor sosial dengan kejadian penyakit demam bedarah (DBD) diketahui tidak ada hubungan kepadatan hunian penduduk dengan kejadian penyakit DBD, ada hubungan mobilitas penduduk dengan kejadian penyakit DBD. Berdasarkan hubungan faktor lingkungan fisik dengan kejadian penyakit demam bedarah (DBD) diketahui ada hubungan kondisi SPAL dengan kejadian penyakit DBD, tidak ada hubungan keberadaan tumpukan ban bekas dengan kejadian penyakit DBD, dan tidak ada hubungan keberadaan Sumur Gali dengan kejadian penyakit DBD. Dan berdasarkan hubungan faktor program pengendalian penyakit DBD dengan kejadian penyakit demam bedarah (DBD) adalah disimpulkan tidak ada hubungan kegiatan penyuluhan DBD, kegiatan kader dan keberadaan jumantik, kegiatan gerakan PSNDBD dengan kejadian penyakit DBD, serta kegiatan fogging dengan kejadian penyakit DBD. 


\section{DAFTAR PUSTAKA}

CNN Indonesia. (2018). Indonesia Peringkat Dua Negara Endemis Demam Berdarah. https://www.cnnindonesia.com/ gayahidup/20160616170332-255-

138672/indonesia-peringkat-dua-negaraendemis-demam-berdarah.

Gama T, A, dan Betty R, F. (2010). Analisis Faktor Risiko Kejadian Demam Berdarah Dengue di Desa Mojosongo Kabupaten Boyolali. Eksplanasi, 2(10).

Green LW., Kreuter MW. (2005). Health Program Planning: An Educational And Ecological Approach; Mc. Graw Hill, Boston.

Hadi, MC., dkk. (2015). Peran Jumantik Dalam Menurunkan Insidens Ratedi Denpasar. Jurnal Skala Husada, Volume 12, Nomor 1, April 2015; 89-95.

Hidayati, L., dkk. (2017). Kejadian Demam Berdarah di Kota Sukabumi Berdasarkan Kondisi Iklim. Acta Veterianaria Indonesiana, Vol. 5, No. 1, (22-28).

Irianty, H., dkk. (2017). Hubungan Sikap dan Upaya Pencegahan Ibu Dengan Kejadian Demam Berdarah Dengue (DBD) di Wilayah Kerja Puskesmas Guntung Payung. Jurnal Publikasi Kesehatan Masyarakat, Vol. 4, No. 2.

Istiqomah, dkk. (2017). Faktor-faktor yang Berhubungan Dengan Upaya Pencegahan Demam Berdarah Dengue (DBD) pada Ibu Rumah Tangga di Keluarahan Kramas Kota Semarang. Jurnal Kesehatan Masyarakat, Volume 4, Nomor 1.

Mantra, IB. (2008). Demografi Umum. Yogyakarta: Pustaka Pelajar.

Murwanto, B. (2013). Karakteristik Penderita Demam Berdarah Dengue (DBD) di RSUD dr. H. Bob Bazar, SKM, Kabupaten Lapung Selatan Tahun 2013. Jurnal Kesehatan Lingkungan, Ruwai Jurai, Volume 7, Nomor 2.

Murwanto, B. (2015). Gambaran Faktor-faktor Determinan Pendetrita Penyakit Demam Berdarah (DBD) di Wilayah Kerja UPT Puskesmas Natar, Kabupaten Lampung Selatan Tahun 2015. Jurnal Citra Keperawatan Politeknik Kesehatan Banjarmasin, Jilid 4, Nomor 1.

Notoatmodjo, S. (2010). Metode Penelitian Kesehatan, Jakarta: Rineka Cipta.
Nugrahaningsih, M., dkk. (2010). Hubungan Faktor Lingkungan dan Perilaku Masyarakat Dengan Keberadaan JentikNyamuk Penular Demam Berdarah Dengue(DBD) di Wilayah Kerja Puskesmas Kuta Utara. Ecotropic, 5 (2):93-97.

Pham, H. V., Doan, H. T., Phan, T. T., \& Minh, N. N. T. (2011). Ecological factors associated with dengue fever in a Central Highlands province, Vietnam. $B M C$ infectious diseases, 11(1), 172.

Rulen, B. N., Siregar, S. H., \& Nazriati, E. (2017). Faktor-faktor Yang Mempengaruhi Keberadaan Jentik Aedes aegypti Terhadap Kejadian Demam Berdarah dengue (DBD) di Kecamatan Payung Sekaki Kota Pekanbaru. Dinamika Lingkungan Indonesia, 4(1), 59-64.

Said, G. Palupi S. (2012). Survei Keberadaan Jentik Nyamuk Aedes spp Pada Sumur Gali Milik Warga Di Kelurahan Bulusan Kota Semarang (Studi Di Wilayah Kerja Puskesmas Rowosari Semarang). Jurnal Kesehatan Masyarakat, Vol. 1 No. 2, Hal. 326-337, UNDIP, Semarang.

Sholehhudin, M., Ma'rufi, I., \& Ellyke, E. (2014). Hubungan Sanitasi Lingkungan, Perilaku Pengendalian Jentik dan Nyamuk, dan Kepadatan Penduduk dengan Penyakit Demam Berdarah Dengue (DBD) di Kabupaten Jember (Relationship of Environmental Sanitation, Mosquito and Larva Control Behavior, and Population De. Pustaka Kesehatan, 2(3), 476-483.

Subagia, K., dkk. (2012). Lingkungan Dalam Rumah, Mobilitas dan Riwayat Kontak Sebagai Determinan Kejadian Demam Berdarah Dengue di Denpasar Tahun 2012; Public Heath and Preventive Medicine Archive, Volume 1, Nomor 1.

Tanjung, M. O. (2012). Perilaku Kader Jumantik Dalam Melaksanakan Psn Dbd 3m Plus Di Kelurahan Jomblang Kecamatan Candisari. Jurnal Kesehatan Masyarakat Universitas Diponegoro, 1(2).

Yunita, J., Mitra, M., \& Susmaneli, H. (2012). Pengaruh Perilaku Masyarakat dan Kondisi Lingkungan Terhadap Kejadian Demam Berdarah Dengue. Jurnal Kesehatan Komunitas, 1(4), 193-198. 